\title{
Occurrence of Cabassous tatouay (Cingulata, Dasypodidae) in Rio Grande do Sul and its potential distribution in southern Brazil
}

\author{
Stefan V. de Oliveira', Luiz L. C. Corrêa², Felipe B. Peters³, Fábio D. Mazim4, Felipe M. Garcias', \\ Janduhy P. dos Santos \& Carlos B. Kasper ${ }^{6}$
}

\begin{abstract}
1. Universidade de Brasília, Programa de Pós-Graduação em Medicina Tropical, Campus Universitário Darcy Ribeiro, Asa Norte, $70910-900$ Brasília, DF, Brazil. (stefanbio@yahoo.com.br)

2.Universidade do Vale do Rio dos Sinos, Programa de Pós Graduação em Biologia, Av. Unisinos, Cristo Rei, 950, 93022-000 São Leopoldo, RS, Brazil. 3.Universidade Luterana do Brasil, Museu de Ciências Naturais, Departamento de Biologia, Avenida Farroupilha, 8001, 92425-900, Canoas, RS, Brazil. 4. Káa aguy Consultoria Ambiental, Rua Padre Anchieta, 1277. Apto. 201, 96015-420 Pelotas, RS, Brazil.

5. Universidade de Brasília, Campus Universitário Darcy Ribeiro, Departamento de Geografia, Asa Norte, 70910-900, Brasília, DF, Brazil.

6. Universidade Federal do Pampa (UNIPAMPA), Campus de São Gabriel, Laboratório de Biologia de Mamíferos e Aves (LABIMAVE) Av. Antônio Trilha, Centro, 1847
\end{abstract} 97300-000, São Gabriel, RS, Brazil.

\begin{abstract}
Cabossous tatouay Desmarest, 1804 is considered a rare species in southern South America, and Rio Grande do Sul State, Brazil, records of the species are scarce and inaccurate. This study reports 40 localities for $C$. tatouay, and provides a map of the species' potential distribution using ecological niche modeling (ENM). The ENM indicated that in this region C. tatouay is associated with open grasslands, including the areas of "Pampas" and the open fields in the highlands of the Atlantic Forest. This study contributes to the information about the greater naked-tailed armadillo in southern Brazil, and provides data key to its future conservation.
\end{abstract}

KEYWORDS. Xenarthra, ecological niche, greater naked-tailed armadillo.

RESUMO. Ocorrência de Cabassous tatouay (Cingulata, Dasypodidae) e seu potencial de distribuição para o sul do Brasil. Cabassous tatouay Desmarest, 1804 é considerada espécie rara no sul da América do Sul, apresentando registros escassos e imprecisos para o Rio Grande do Sul. O presente estudo descreve 40 localidades de ocorrência de C. tatouay e apresenta de um mapa de distribuição geográfica potencial, gerado por Modelagem Ecológica de Nicho. A modelagem de nicho sugere uma associação da espécie com áreas de matriz campestre, incluindo o Pampa e os Campos de Cima da Serra, associados à Mata Atlântica. Este estudo contribui para o melhor conhecimento do tatu-de-rabo-mole no Sul do Brasil e fornece dados-chave para sua conservação.

PALAVRAS-CHAVE. Xenarthra, nicho ecológico, tatu-do-rabo-mole.

Cingulata belonging to the genus Cabassous Mc Mutrie, 1831, are represented by four formally described species (GARDNER, 2005) of which two occur in Brazil (Paglia et al., 2012; Hayssen, 2014): Cabassous tatouay Desmarest, 1804, and C. unicinctus (Linnaeus, 1758). The lack of physical records of these two armadillos in national scientific collections, and their infrequent appearance on local inventories, limit detailed studies on their taxonomy, phylogeny, geographical distribution, and conservation status (FonseCa et al., 1996; NowaK, 1999; ANACLETO et al., 2006).

That Cabassous tatouay, greater naked-tailed armadillo, is a poorly known species has been reported by Wetzel (1982), REDFORd (1985), Ubaid et al. (2010), GonZaLES \& LANFranco (2010) and Hayssen (2014). The southernmost records of the species are from the Uruguayan provinces of Maldonado and Lavalleja (CoITIÑ et al., 2013). From here the range extends northwards to the state of Pará, in northern Brazil. In between the species has been recorded from the southern, southeastern, and central regions of Brazil (HAYsSEN, 2014). It is also found in southern Paraguay (HAYSSEN, 2014) and northeastern Argentina, where it appears restricted to Misiones province (АвBA et al., 2012).

In southern Brazil, the species appears in the regional listings of both IHERING (1892) and SiLVA (1994), but in both cases without any information on location or habitat. OliveIRA \& Vilella (2003) mentioned the occurrence of $C$. totouay in the west and southwest regions of the state, and KASPER et al. (2007) indicated the occurrence of this species in the central region of RS, where it may be in population decline. The only accurate and confirmed record is from an archaeological site located at east of State, associated to pioneer formations under fluvial influence of the Rio Grande basin. An assessment of potential geographic ranges of armadillos in Brazil (ANACLETO et al., 2006) highlighted the small number of $C$. tatouay records, and suggested that Brazilian Pampa was not a favored habitat. Indeed, C. tatouay does seem relatively uncommon in this habitat, except in Uruguay, the southern limit of its distribution, where some 10 records are available from the Pampas (CoITIÑo et al., 2013).

There are few ecological data from the northernmost part of the range of C. tatouay. Medri et al. (2011) pointed to the occurrence of the species in forested areas, and its absence from areas of intensive agriculture or severely degraded localities. According to CARTER \& ENCARNAÇ̃̃o (1983), C. tatouay changes its burrow every day, and does not use the same shelter twice. MedRi et al. (2011) reported that the species has a home range of some 
409 hectares, feeds exclusively on ants, is predominantly crepuscular or nocturnal, and has only a single offspring at any one time.

The greater naked-tailed armadillo is considered of Least Concern at the global level, with only minor conservation action being proposed (GonZALES \& ABBA, 2014). However, all available information on the species in Brazil has been derived from a handful of wild-based observations, and these are insufficient to assess the status of the species in the country (CHIARELlo et al., 2008). Cabassous tatouay is considered vulnerable to extinction in Uruguay, and is a national priority for conservation (Gonzales \& Lanfranco, 2010). With regard to Rio Grande do Sul, there is no precise information on the population status or even the basic inventories to enable analysis of the current distribution of the species (OLIVEIRA \& Vilella, 2003).

Thus, the present study aims to contribute to the knowledge of $C$. tatouay in RS by reporting new areas of occurrence, expanding the known distribution of the species, and providing a map of its potential distribution using ecological niche modeling.

\section{MATERIAL AND METHODS}

Cabassous tatouay distributional data. All records of C. tatouay were obtained between 2000 and 2012 through monitoring and inventories of mammals in different regions of the Rio Grande do Sul State, plus records of opportunity. The main methods employed were: camera trap records, searching for tracks and signs, nocturnal censuses, ad libitum observations, and monitoring mammalian roadkill on regional highways. The results were part of a general program of mammal surveys in the state and did not specifically target $C$. tatouay and covered a range of regional environments. Thus, any reported habitat selection is not the result of selectivity in survey design.

Specimens found dead and with good conditions were deposited in the scientific collections of the Museu de Ciências Naturais, Universidade Luterana do Brasil, Canoas, RS. For specific determination of C. tatouay, we followed EISENBERg \& REDFORD (1999), ACHAVAL et al. (2007), Medri et al. (2011), and GonZales \& LANFRANCO (2010) in using the following as diagnostic external characteristics: body large and robust (6-12 kg), shell with 10-13 flexible dorsal bands and tail lacking osteoderms; head large, cephalic shield with symmetrical plates; ears large, widely-separated, and with granular external surface; snout short and wide; front and back legs both with five digits, and large nails, especially on the third digit; dental formula varying between 7 to 10 upper, and 8 to 9 lower teeth. Sampling sites were widely dispersed throughout RS state, and a variety of habitat types including forests, open fields in the highlands of the Atlantic Forest, and formations of Brazilian Pampas. All records of $C$. tatouay were georeferenced.

Ecological niche modeling. A potential distribution map was produced using the Maxent algorithm version 3.2.1 (Phillips et al., 2006) by applying the basic parameters suggested by the program and deploying randomization of training points (random seed). Overlapping or very close points were removed, and C. tatouay records were divided into two sets, one for training $(75 \%$ of points to run the model) and the other for testing (25\% of points to evaluate the model). The model of potential geographical distribution generated by Maxent was then imported and edited by the ArcView 3.3 program.

The quality of the model prediction was evaluated using ROC (Receiver Operating Characteristics) that relates the sensitivity and specificity parameters of the model (Phillips et al., 2006). The calculation of the area under the ROC curve, also known as Area Under the Curve (AUC), provides a single measure of the model performance. The AUC ranges from 0 to 1 , where values close to 1 indicate high performance, while those less than 0.5 indicate poor performance (Peterson et al., 2008). To evaluate the sensitivity, we tracked the number of test points present in the area predicted by the model (ELITH et al., 2006). To identify the variables that most influenced the distribution of C. tatouay, we ran a Jackknife test using Maxent (PHILLIPS et al., 2006). This test measures the predictive effects of each variable in the model when verifying the quality of the model only with the variable in test and the omitted variable in test.

Seven predictor variables were used (Tab. I). These variables were obtained from the Modeling Group for Biodiversity Studies, of the Brazilian Institute for Space Research, AMBDATA/INPE (http://www.dpi.inpe.br/ Ambdata/referencias.php). All environmental information was organized in grids in the ASCII-raster format, using the geodetic coordinate projection system "Lat Long," Datum WGS-84, with a spatial resolution of 30 arc-seconds or approximately $1 \mathrm{~km}^{2}$.

\section{RESULTS}

Field observations registered 40 occurrences of $C$. tatouay from 30 municipalities within RS. Twenty-seven sites were located in the Pampa biome, eleven in the Atlantic Forest, and two in the areas of transition from Pampa biome to Atlantic Forest (IBGE, 2004) (Tab. II). A total of twelve specimen records were obtained by identifying tracks, ten individuals were directly observed, nine carcasses were obtained from hunters, five carcasses were found as highway roadkill, and four individuals were recorded with camera traps.

For ecological niche modeling, 37 spatially unique records were used. Annual average temperature was the variable that most influenced the model distribution of $C$. tatouay, followed by precipitation in driest month (Tab. II).

The operating characteristic (OC) curve evaluates the performance of the model. OC analysis gave a value of 0.99 , which is regarded as excellent, and indicates that the results were not random. As evaluated by the 
Tab. I. Predictor variables used in the ecological niche modeling of Cabassous tatouay Desmarest, 1804 for the State of Rio Grande do Sul, Brazil.

\begin{tabular}{llc}
\hline Name & Environmental Variable & Percent contribution \\
\hline Altitute_br & Altitude & 2.3 \\
Bio1_br & Average annual temperature & 52.3 \\
Bio2_br & Average diurnal temperature variation & 6.8 \\
Bio5_br & Maximum temperature of warmest month & 0 \\
Bio6_br & Minimum temperature of coldest month & 1.1 \\
Bio7_br & annual precipitation & 0 \\
Bio13_br & Precipitation of wettest month & 6.9 \\
Bio14_br & Precipitation of driest month & 28.3 \\
Sa2010_Tree & Percent arboreal coverage & 2.3 \\
\hline
\end{tabular}

Tab. II. Confirmed localities for Cabassous tatouay Desmarest, 1804 in the State of Rio Grande do Sul, Brazil, 2000-2012, with record date, type of observation, municipality, biome, anthropogenic matrix, and human density (DO, Direct observation; PP, Pawprint; HU, Hunted; RK, Roadkill; CT, Camera trap; RE, Record; BI, Biome; AF, Atlantic Forest; PA, Pampa).

\begin{tabular}{|c|c|c|c|c|c|c|c|}
\hline Date & $\mathrm{RE}$ & City & Latitude & Longitude & $\mathrm{BI}$ & Anthropogenic matrix & Human density \\
\hline 2004 & CT & São Francisco de Paula & -31.0427 & -54.5375 & $\mathrm{AF}$ & livestock and Pinus & low, latifundia \\
\hline 2004 & RK & Santana do Livramento & -29.95972 & -50.6711 & PA & livestock & low, latifundia \\
\hline 2004 & DO & Piratini & -28.8063 & -50.6131 & PA & eucalyptus and livestock & low, latifundia \\
\hline 2004 & DO & Tapes & -30.61411 & -53.53258 & PA & $\begin{array}{l}\text { landscape and forest fragments altered } \\
\text { by planting eucalyptus and rice }\end{array}$ & low, latifundia \\
\hline 2005 & RK & Cambará do Sul & -30.2961 & -53.53777 & $\mathrm{AF}$ & livestock and Pinus & low, latifundia \\
\hline 2005 & PP & São Francisco de Paula & -30.2913 & -53.7605 & $\mathrm{AF}$ & livestock and Pinus & low, latifundia \\
\hline 2005 & $\mathrm{PP}$ & Maquiné & -30.37055 & -53.6008 & $\mathrm{AF}$ & cyclical monocultures & low, latifundia \\
\hline 2005 & DO & Capão do Leão & -30.35107 & -51.0405 & PA & eucalyptus, soya, and livestock & $\begin{array}{l}\text { high, minifundios, } \\
\text { and urbanization }\end{array}$ \\
\hline 2005 & DO & Arroio Grande & -30.6966 & -49.5224 & PA & eucalyptus, soya, and livestock & low, latifundia \\
\hline 2006 & DO & Rosário do Sul & -28.2333 & -51.1833 & PA & eucalyptus, livestock, rice, and soya & low, latifundia \\
\hline 2006 & $\mathrm{PP}$ & Manoel Viana & -28.33305 & -50.6966 & PA & eucalyptus, livestock, rice, and soya & low, latifundia \\
\hline 2006 & PP & São Francisco de Assis & -28.33611 & -50.6755 & PA & eucalyptus, livestock, rice, and soya & low, latifundia \\
\hline 2006 & DO & Alegrete & -29.03027 & -51.41916 & PA & eucalyptus, livestock, rice, and soya & low, latifundia \\
\hline 2007 & RK & São Francisco de Paula & -30.41722 & -53.43638 & $\mathrm{AF}$ & livestock, Pinus, and cyclical monocultures & low, latifundia \\
\hline 2007 & PP & Piratini & -28.80607 & -50.51680 & PA & eucalyptus, Pinus, and livestock & low, latifundia \\
\hline 2007 & HU & Caçapava do Sul & -31.58091 & -53.47975 & PA & eucalyptus, soya, and livestock & low, latifundia \\
\hline 2007 & RK & São Sepé & -31.02008 & -53.66596 & PA & $\begin{array}{l}\text { natural grasslands and forest fragments changed } \\
\text { by livestock and planting of soya }\end{array}$ & low, latifundia \\
\hline 2008 & $\mathrm{HU}$ & Dom Pedrito & -32.09612 & -53.58937 & PA & $\begin{array}{l}\text { natural rocky grassland and forest fragment used } \\
\text { extensively by livestock }\end{array}$ & low, latifundia \\
\hline 2008 & DO & Alegrete & -31.775259 & -53.80291 & PA & $\begin{array}{l}\text { rupestrian field and forest fragment used } \\
\text { extensively by livestock }\end{array}$ & low, latifundia \\
\hline 2009 & RK & Viamão & -30.6155 & -51.3625 & $\mathrm{AF} / \mathrm{PA}$ & livestock, rice, and urbanization & low, latifundia \\
\hline 2009 & PP & Encruzilhada do Sul & -31.84310 & -53.5854 & PA & eucalyptus, soya, and livestock & low, latifundia \\
\hline 2010 & DO & Pedras Altas & -29.0829 & -50.3666 & PA & eucalyptus and livestock & low, latifundia \\
\hline 2010 & RK & Santana da Boa Vista & -31.29572 & -53.47415 & PA & eucalyptus, soya, and livestock & low, latifundia \\
\hline 2010 & RK & Caçapava do Sul & -30.5644 & -52.15723 & PA & $\begin{array}{c}\text { natural rocky grasslands and forest fragment used } \\
\text { extensively by livestock }\end{array}$ & low, latifundia \\
\hline 2011 & PP & Piratini & -28.72910 & -50.4208 & PA & eucalyptus and livestock & low, latifundia \\
\hline 2011 & RK & Pinheiro Machado & -29.3562 & -50.2208 & PA & eucalyptus and livestock & low, latifundia \\
\hline 2011 & $\mathrm{PP}$ & Herval & -29.4882 & -50.3381 & PA & eucalyptus and livestock & low, latifundia \\
\hline 2011 & PP & Bagé & -29.665037 & -55.20817 & PA & eucalyptus, soya, and livestock & low, latifundia \\
\hline 2011 & $\mathrm{PP}$ & Bagé & -29.66503 & -49.20817 & PA & eucalyptus, soya, and livestock & low, latifundia \\
\hline 2011 & $\mathrm{CT}$ & Muitos Capões & -30.49141 & 54.98310 & $\mathrm{AF}$ & $\begin{array}{l}\text { landscape and forest fragmentation, with } \\
\text { Araucaria forest altered by soy planting } \\
\text { natural rocky grassland and Araucaria forest }\end{array}$ & low, latifundia \\
\hline 2011 & $\mathrm{DO}$ & Bom Jesus & -29.44003 & -55.41661 & $\mathrm{AF}$ & $\begin{array}{c}\text { fragment used extensively for livestock and } \\
\text { planting Pinus } \\
\text { natural rocky grassland and Araucaria forest }\end{array}$ & low, latifundia \\
\hline 2011 & $\mathrm{CT}$ & Bom Jesus & -31.77767 & -52.59165 & $\mathrm{AF}$ & $\begin{array}{c}\text { natural rocky grassland and Araucaria forest } \\
\text { fragment used extensively for livestock and } \\
\text { planting Pinus }\end{array}$ & low, latifundia \\
\hline 2012 & DO & Bom Jesus & -30.6038 & -55.0952 & $\mathrm{AF}$ & livestock and Pinus & low, latifundia \\
\hline 2012 & $\mathrm{PP}$ & Bom Jesus & -29.9625 & -55.3538 & $\mathrm{AF}$ & livestock and Pinus & low, latifundia \\
\hline 2012 & $\mathrm{PP}$ & Hulha Negra & -30.49090 & -48.98260 & PA & eucalyptus, livestock, rice, and soya & low, latifundia \\
\hline 2012 & RK & São Sepé & -31.18200 & -54.0751 & PA & $\begin{array}{l}\text { landscape and forest fragments changed by } \\
\text { livestock and soy planting }\end{array}$ & high, minifundios \\
\hline 2012 & $\mathrm{CT}$ & $\begin{array}{l}\text { Santo Antônio da } \\
\text { Patrulha }\end{array}$ & -30.6961 & -55.52188 & $\mathrm{AF} / \mathrm{PA}$ & $\begin{array}{c}\text { landscape and forest fragments altered } \\
\text { by planting rice }\end{array}$ & low, latifundia \\
\hline 2012 & $\mathrm{HU}$ & Nova Roma do Sul & -29.5925 & -50.1788 & $\mathrm{AF}$ & forest fragment on hillside modified by viticulture & low, latifundia \\
\hline 2013 & $\mathrm{HU}$ & Rosário do Sul & -32.103349 & -53.10558 & PA & $\begin{array}{l}\text { natural rocky grassland and forest fragment used } \\
\text { extensively for livestock and planting Eucalyptus }\end{array}$ & low, latifundia \\
\hline 2013 & $\mathrm{HU}$ & São Sepé & -30.97692 & -53.05377 & PA & $\begin{array}{l}\text { landscape and forest fragments changed by } \\
\text { livestock and soy planting }\end{array}$ & $\begin{array}{l}\text { high, minifundios, } \\
\text { and urbanization }\end{array}$ \\
\hline
\end{tabular}


test points, model sensitivity was $100 \%$, and all the test points positioned in the potential distribution area (Fig. 1).

\section{DISCUSSION}

Ecological niche modeling results (Fig. 2) showed the areas most ecological and geographic suitable for $C$. tatouay were associated with the two main mountainous areas of Rio Grande do Sul State, and the valley between them. In our model the areas with highest scores were Serra Geral in northeastern (with altitudes of $700-1400 \mathrm{~m}$ ), "Serra do Sudeste" in southeast, and the "Planície Central", a relatively flat area, between these two montainous regions (Fig. 2). Gallery forests appear to be strongly linked with C. tatouay presence, especially when associated with areas o rock-rich natural grasslands. However, even disturbed areas with farming and the extensive cultivation of soya, rice, or exotic trees were used by the greater naked-tailed armadillo. In the generated ecological niche model, the most important variables for determining C. tatouay presence were average annual temperature (responsible for $52.3 \%$ of the variance), and precipitation in driest month (28.3\%). These variables were similar to other models for the species, like presented by ABBA et al. (2012) and CoITIÑo et al. (2013).

Because of the heterogeneity of sampling methods, it is impossible to fully quantify the expended sampling effort. However, it is possible to we are confident that the absence of records in north-northwest portion of the state reflects, if not absence, low densities of this species.
There were also no records of $C$. tatouay in pioneer formations under marine influence in the east. However, it is interesting to note that $67.5 \%$ of our records came from Pampas region, a biome that the species is not considered to prefer (ANACLETO et al., 2006). We present here more records of $C$. tatouay for Pampas region than ANACLETO et al. (2006) for all Brazil. Exactly why this is so requires further consideration, since the species seems genuinely uncommon in Pampas landscapes in neighboring Argentina and Uruguay (ABBA et al., 2012; CoITIÑo et al., 2013).

Approximately $12.5 \%$ of the records came from roadkill. While this demonstrates that highways may be a threat to the conservation of C. tatouay. The extent of this impact cannot currently be measured, because of the lack of systematic sampling targeted at locations where roadkill was confirmed. Although the available studies on this subject are scarce and have not reported C. tatouay (RosA \& Mahus, 2004; Tumeleiro et al., 2006; HengemüHLE \& CADEMARTORI, 2008), FontanA et al. (2003) listed roadkill as the direct cause of population decline of $2.5 \%$ of the species of conservation interest in RS. Indeed the frequency of roadkill may be higher than estimated here, since many animals survive the initial impact only to die concealed in vegetation a few meters from the road. Moreover, unless surveys are frequent, roadkill frequencies may be underestimated because of scavengers: at least some of which are human (on one occasion, a local habitant asked for the carcass while we were examining it). In combination, this shows the need for urgent action by the licensing agencies in Rio Grande do Sul state to implement existing

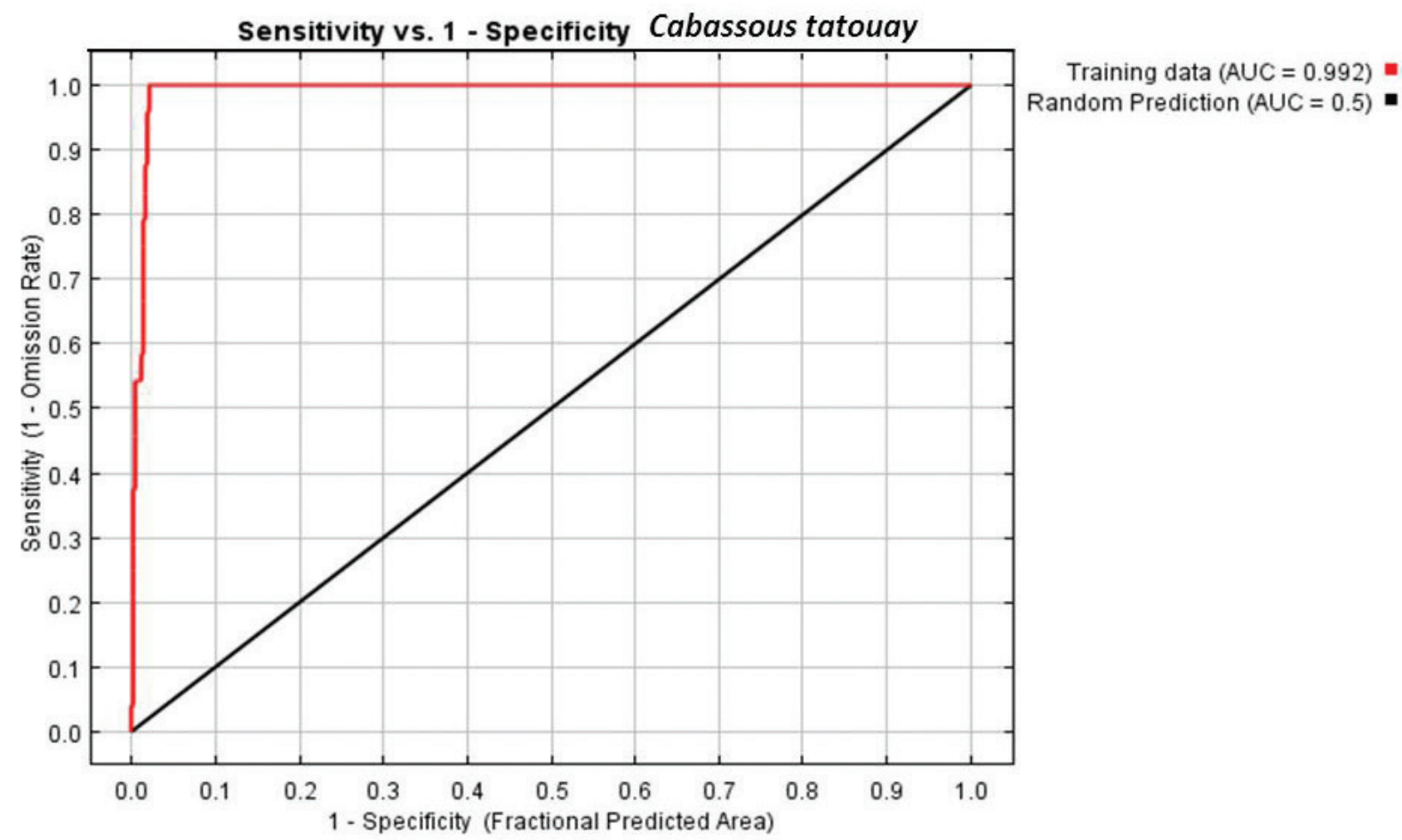

Fig. 1. Area Under the Curve produced by the Maxent algorithm, plus sensitivity and specificity response of the ecological niche model for Cabassous tatouay Desmarest, 1804 for the State of Rio Grande do Sul, Brazil. 


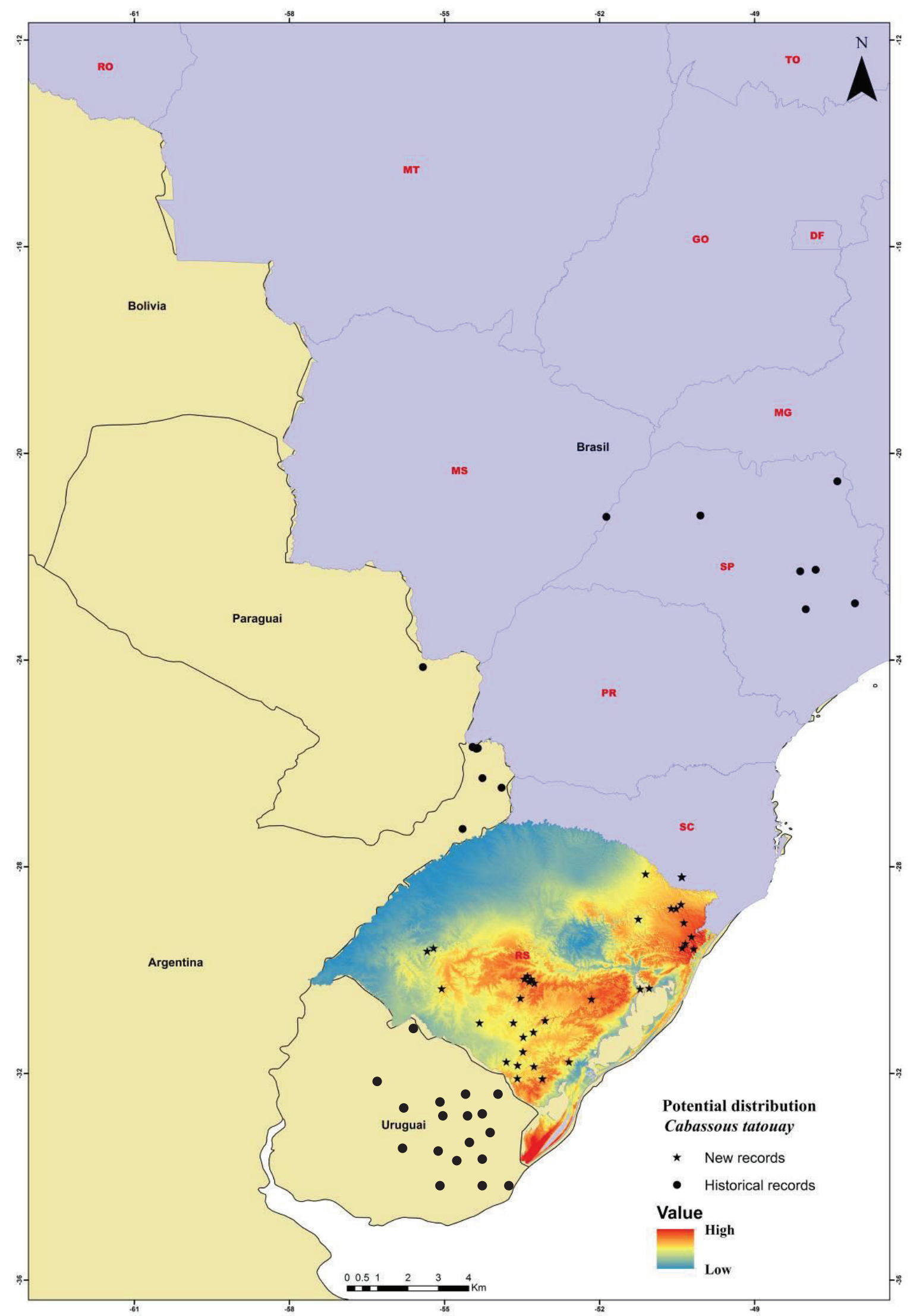

Fig. 2. Model ecological niche of Cabassous tatouay Desmarest, 1804 produced by Maxent algorithm, and a visualization of its potential distribution in the state of Rio Grande do Sul, Brazil. Stars indicate new locality records for the species, circles indicate historical records to the present study within South America. 
regulations on the construction of highways in manners that mitigate and minimize the potential for vehicle-related deaths in wildlife living in proximity to highways, and to do this for both existing highways and those under construction or undergoing widening or expansion.

About $22 \%$ of records were obtained from local hunters, confirming the data of PETERs et al. (2011), who reported Dasypodidae to be one of the mammalian groups most impacted by hunting in southwestern RS. Although illegal, this activity is driven by the consumption of meat, armadillo hunting is not the results of nutritional need, but instead is a recreational and cultural practice. As the naked-tailed armadillo is the largest species of armadillo, found in the RS, it is preferred over smaller species such as Dasypus novemcinctus Linnaeus, 1758, Dasypus hybridus Desmarest, 1804, and Euphractus sexcinctus Linnaeus, 1758 .

The records collected in the current study, are insufficient to estimate population trends for C. tatouay. However, it is possible to say that $C$. tatouay can currently be considered one of the rarest species of mid-size mammal in RS. Other species of armadillo are easily recorded as roadkill, and by direct observations and camera traps. When compared with the number of records obtained during the study of other Cingulata and of species from other groups of mid-sized mammals considered as endangered (such as carnivores), it is likely that $C$. tatouay is now under the threat of regional extinction in RS state. Therefore, it is suggested that conservation actions be directed at $C$. tatouay, especially in regions indicated as having high ecological and geographical suitability for the species. These actions could involve: the creation of local of field stations or nature parks that have armadillo protection as their prime focus; the implementation of wildlife-friendly construction for existing and new highways; active counterhunting surveillance; enforcement of existing legislation; and encouraging future studies that monitor C. tatouay population trends in RS (as well other areas within its natural range).

Acknowledgments. We thank Lissandro Moraes and Mauricio Pereira da Silveira for making the specimen record available. Adrian A. Barnett for English review and comments to manuscript. Permission for collecting specimens was granted by IBAMA and FEPAM (license number 158/2009, 185/2009, 239/2009, 06/2010, 611/2011-DL, among the others).

\section{REFERENCES}

Abba, A. M.; Tognelli, M. F.; Seitz, V. P.; Bender, J. B. \& Vizcaíno, S. F. 2012. Distribution of extant xenarthrans (Mammalia: Xenarthra) in Argentina using species distribution models. Mammalia 76:123-136.

Achaval, F.; Clara, M. \& Olmos, M. C. 2007. Mamíferos de la República Oriental del Uruguay, guia fotográfica. 2ed. Montevideo, Zonalibro Indústria Gráfica. 216p.

Anacleto, T. C. S.; Diniz Filho, J. A. F. \& Vital, M. V. C. 2006. Estimating potential geographic ranges of armadillos (Xenarthra, Dasypodidae) in Brazil under niche-based models. Mammalia 70(3-4):202-213.

Carter, T. S. \& Encarnação, C. D. 1983. Characteristics and Use of Burrows by Four Species of Armadillos in Brazil. Journal of Mammalogy 64:103-108.
Chiarello, A. G.; Aguiar, L. M. S.; Cerqueira, R.; Melo, F. R.; Rodrigues, F. H. G. \& Silva, V. M. 2008. Mamíferos ameaçados de extinção do Brasil. In: Machado, A. B. M.; Drummond, G. M. \& Paglia, A. P. orgs. Livro Vermelho da Fauna Brasileira Ameaçada de Extinção. Belo Horizonte, Brasília, Ministério do Meio Ambiente, Fundação Biodiversitas, p. 681-702.

Coitiño, H. I.; Montenegro, F.; Fallabrino, A.; Gonzáles, E. M. \& HernáNDEZ, D. 2013. Distribuición actual y potencial de Cabassous tatouay y Tamandua tetradactyla en el limite sur de su distribución: implicâncias para su conservación em Uruguay. Edentata 14:23-34.

EisenBerG, J. F. \& REDFORD, K. H. 1999. Mammals of the Neotropics: the central Neotropics. Volume 3. Chicago, University of Chicago Press. 339p.

Elith, J. C. C.; Graham, R.; Anderson, M.; Dudík, S.; Ferrier, A.; Guisan, R.; Hijmans, F.; Huettmann, J.; Leathwick, A.; Lehmann, J. L. I.; Lohmann, L.; Loisell, B.; Manion, G.; Moritz, C.; Nakamura, M.; Nakazawa, Y.; Overton, J.; Peterson, A. T.; Phillips, S.; Richardson, K.; Scachetti-Pereira, R.; Schapire, E.; Soberón, J.; Williams, S.; Wisz, M. \& Zimmerman, N. 2006. Novel methods improve prediction of species distributions from occurrence data. Ecography 29:129-151.

Fonseca, G. A. B.; Hermann, G.; Leite, Y. L. R.; Mittermeier, R. A.; Rylands, A. B.\& Patton, J. L. 1996. Lista anotada dos mamíferos do Brasil. Occasional Papers in Conservation Biology 4:1-38.

Fontana, C. S.; Vélez, E.; Bencke, G. A. \& Reis, R. E. orgs. 2003. Livro Vermelho da Fauna Ameaçada de Extinção no Rio Grande do Sul. Porto Alegre, EDIPUCRS/Fundação Zoobotânica do Rio Grande do Sul. 632p.

GARDNER, A. L. 2005. Order Cingulata. In: Wilsonand, D. E. \& ReEder, D. M. eds. Mammal Species of the World: a taxonomic and geographic reference. 3ed. Baltimore, The Johns Hopkins University Press, p. 94-99.

GonZalez, E. \& ABba, A. M. 2014. Cabassous tatouay. The IUCN Red List of Threatened Species. Version 2015.1. Avaliable at $<$ www. iucnredlist.org $>$. Accessed on 16 June 2015.

Gonzales, E. M. \& Lanfranco, J. A. M. 2010. Mamíferos de Uruguay. Guía de Campo e Introducción a su Estudio y Conservación. Montevideo, Banda Oriental/Vida Silvestre/MNHN. 464p.

Hayssen, V. 2014. Cabassous chacoensis (Cingulata: Dasypodidae). Mammalian Species 46:24-27.

HengemüHLe, A. \& CAdemartori, C. V. 2008. Levantamento de mortes de vertebrados silvestres devido a atropelamento em um trecho da estrada do mar (RS-389). Biodiversidade Pampeana 6(2):4-10.

IBGE. 2004. Mapa de Vegetação do Brasil, Esc. 1:5.000.000. Available at $<\mathrm{ftp}$ ://ftp. ibge.gov.br/Cartas_e_Mapas/Mapas_Murais/>. Accessed on 20 October 2012.

IHering, H. V. 1892. Os mamíferos do Rio Grande do Sul. Annuário do Estado do Rio Grande do Sul 1892:43-77.

Kasper, C. B.; Feldens, M. J.; Mazim, F. D.; Schneider, A.; Cademartori, C. V. \& Grillo, H. C. Z. 2007. Mamíferos do Vale do Taquari, região central do Rio Grande do Sul. Biociências 15:53-62.

Medri, I. M.; Mourão, G. \& Rodrigues, F. H. G. 2011. Ordem Xenarthra. In: Reis, N. R.; Peracchi, A. L.; Pedro, W. A. \& LIMA, I. P. eds. Mamíferos do Brasil. Londrina, Midiograf, p. 71-99.

NowaK, R. M. 1999. Walker's Mammals of the World. 6ed. V.1. Baltimore, The Johns Hopkins University Press. 836p.

Oliveira, E. V. \& Vilella, F. S. 2003. Xenarthros. In: Fontana, C. S.; Bencke, G. A. \& ReIs, R. E. eds. Livro Vermelho da fauna ameaçada de extinção no Rio Grande do Sul. Porto Alegre, EDIPUCRS, p. 487-492.

Paglia, A. P.; Fonseca, G. A. B.; Rylands, A. B.; Herrmann, G.; Aguiar, L. M. S.; Chiarello, A. G.; Leite, Y. L. R.; Costa, L. P.; Siciliano, S.; KierulfF, M. C. M.; Mendes, S. L.; Tavares, V. C.; Mittermeier, R. A. \& Patton, J. L.. 2012. Lista Anotada dos Mamíferos do Brasil/Annotated Checklist of Brazilian Mammals. Occasional Papers in Conservation Biology 6:1-76.

Peters, F. B.; Roth, P. R. O.; Piske, A. D.; Pereira, M. S. \& Christoff, A. U. 2011. Aspectos da caça e perseguição aplicada a mastofauna na APA do Ibirapuitã, Rio Grande do Sul, Brasil. Biodiversidade Pampeana 9(1):16-19. 
Peterson, A. T.; Papes, M. \& Soberón, J. 2008. Rethinking receiver operating characteristic analysis applications in ecological niche modeling. Ecology Model 21:63-72.

Phillips, S. J.; Anderson, R. P. \& Schapire, R. E. 2006. Maximum entropy modeling of species geographic distributions. Ecology Model 190:231-259.

REDFORD, K. H. 1985. Foods habits of armadillos (Xenarthra: Dasypodidae). In: Montgomery, G. G. ed. The Evolution and Ecology of Sloths, Armadillos, and Vermilinguas. Washington, Smithsonian Institution Press, p. 429-437.

RosA, A. O. \& Mauns, J. 2004. Atropelamento de animais silvestres na rodovia RS-040. Caderno de Pesquisa Série Biologia 16(1):35-42.

Silva, F. 1994. Mamíferos silvestres do Rio Grande do Sul. Porto Alegre, Fundação Zoobotânica do Rio Grande do Sul. 255p.
Tumeleiro, L. K.; Koenemann, J.; Ávila, M. C. N.; Pandolfo, F. R. \& OliveirA, E. V. 2006. Notas sobre mamíferos da região de Uruguaiana: estudo de indivíduos atropelados com informações sobre a dieta e conservação. Biodiversidade Pampeana 4(1):38-41.

Ubaid, F. K.; MendonçA, L. S. \& Maffei, F. 2010. Contribuição ao conhecimento da distribuição geográfica do Tatu-de-Rabo-MoleGrande Cabassous tatouay no Brasil: revisão, status e coméntarios sobre a espécie. Edentata 11:22-28.

Wetzel, R. M. 1982. Systematics, distribution, ecology, and conservation of South American Edentates. In: Mares, M. A. \& Genoways, H. H. eds. Mammalian Biology in South America. Pittsburgh, Special Publication Series of the Pymatuning Laboratory of Ecology, p. 34-375. 